\title{
Distribution of Cold-Adapted Ammonia-Oxidizing Microorganisms in the Deep-Ocean of the Northeastern Japan Sea
}

\author{
TATSUNORI NAKAgAWA ${ }^{1 *}$, KOJI MORI ${ }^{2}$, CHIAKI KATO $^{3}$, ReIJI TAKAHASHI ${ }^{1}$, and TATSUAKi TOKUYAMA ${ }^{1}$ \\ ${ }^{1}$ Department of Agricultural and Biological Chemistry, College of Bioresource Sciences, Nihon University, \\ 1866 Kameino, Fujisawa, Kanagawa 252-8510, Japan \\ ${ }^{2}$ Biological Resource Center (NBRC), Department of Biotechnology, National Institute of Technology and \\ Evaluation (NITE), 2-5-8 Kazusakamatari, Kisarazu, Chiba 292-0818, Japan \\ ${ }^{3}$ Extremobiosphere Research Center, Japan Agency for Marine-Earth Science and Technology (JAMSTEC), 2-15 \\ Natsushima-cho, Yokosuka, Kanagawa 237-0061, Japan
}

(Received July 11, 2007-Accepted August 25, 2007)

We investigated the quantities and phylogenies of amoA genes of ammonia-oxidizing archaea (AOA) belonging to Crenarchaeota and ammonia-oxidizing bacteria (AOB) belonging to Betaproteobacteria in water columns and deep-ocean cold seep sediment in the northeastern Japan Sea with a competitive PCR (cPCR) assay. Water samples were collected at depths of $2000 \mathrm{~m}$ and $2956 \mathrm{~m}$. Sediment samples were collected where white bacterial mats had developed. The cPCR analysis revealed five to ten times more AOA than betaproteobacterial AOB in both the water columns and sediment. The abundance of the crenarchaeotal amo $A$ gene was estimated at $6 \times 10^{1}$ and $3 \times 10^{2}$ copies $\mathrm{ml}^{-1}$ in the water columns at depths of $2000 \mathrm{~m}$ and $2956 \mathrm{~m}$, and $1 \times 10^{8}$ and $1 \times 10^{7} \mathrm{copies}^{-1}$ in pelagic brown sediment and black sediment, respectively. Most archaeal amo $A$ clones from water column at $2000 \mathrm{~m}$ fell into the Deep Marine Group. Most archaeal amoA clones from pelagic brown sediment were less closely related to known environmental clones. Moreover, incubation experiments revealed nitrite production at $4^{\circ} \mathrm{C}$ and $10^{\circ} \mathrm{C}$. The results indicate that psychrophilic AOA and AOB may be responsible for nitrification in the deep-ocean region of the northeastern Japan Sea.

Key words: ammonia-oxidizing archaea, ammonia-oxidizing bacteria, amoA, Crenarchaeota, psychrophilic

Ammonia-oxidizing microorganisms (AOM) utilize ammonia as their major source of energy and carbon dioxide as their main source of carbon. They catalyze the conversion of ammonia $\left(\mathrm{NH}_{3}\right)$ to nitrite $\left(\mathrm{NO}_{2}^{-}\right)$and are widespread in biospheres such as the sea, freshwater, and soil. Hence, AOM play an important role in the global nitrogen cycle.

Ammonia monooxygenase (AMO) is a key enzyme that catalyzes the reaction producing hydroxylamine during the bacterial oxidation of ammonia. The widespread distribution and phylogenetic diversity of ammonia-oxidizing bacteria (AOB) belonging to the Betaproteobacteria in natural environments such as the sea, freshwater, and soil have

\footnotetext{
* Corresponding author. E-mail address: nakatats@brs.nihon-u.ac. jp; Tel.: +81-466-84-3359; Fax: +81-466-84-3359.
}

been demonstrated by using a molecular ecological approach based on the $\alpha$ subunit of the AMO (amoA) gene $^{4,5,19,24,26,30)}$. The amo $A$ genes affiliated with the Gammaproteobacteria have been found in the ocean upper depth of $1000 \mathrm{~m}^{32}$. More recently, an environmental genomic study has suggested that ammonia-oxidizing archaea (AOA) exist in soil because a novel amo $A$ gene was found in the same metagenomic fragment accompanied with 16S rRNA gene of Crenarchaeota ${ }^{28)}$. Isolation of the ammonia-oxidizing archaeon 'Candidatus Nitrosopumilus maritimus' belonging to the marine group I Crenarchaeota has indicated a definitive link between the novel amo $A$ gene and archaeal ammonia oxidation ${ }^{14)}$. Several studies with different sets of PCR primers for the archaeal amoA gene have demonstrated the worldwide distribution and phylogenetic diversity of AOA in natural environments $3,7,9,16,20,31)$. 
The ocean is cold (less than $5^{\circ} \mathrm{C}$ ) at depths of more than $1000 \mathrm{~m}$. The ratio of nonthermophilic archaea to all planktonic prokaryotes increases gradually in deeper water columns of the ocean ${ }^{13)}$. Marine Group I Crenarchaeota are relatively abundant among all archaea in deep-water columns of the meso- and bathypelagic oceans at more than $1000 \mathrm{~m}^{10,13)}$. Positive correlations between the abundance of Crenarchaeota and nitrite were observed in the Arabian $\mathrm{Sea}^{27)}$. A lipid analysis with a compound-specific isotopebased approach demonstrated that $\mathrm{CO}_{2}$ was a major carbon source for Crenarchaeota in the mesopelagic ocean at 670 $\mathrm{m}^{12)}$. An enrichment culture of coastal water of the North Sea suggested that mesophilic Crenarchaeota contributed mainly to the oxidization of ammonia ${ }^{33)}$. Furthermore, the abundance of archaeal amo $A$ genes was greater than that of bacterial amo $A$ in the upper (less than $1000 \mathrm{~m}$ ) open ocean of the Atlantic ${ }^{33)}$. These results suggested a significant role for AOA in nitrification in the ocean. However, relatively little is known about the ratio of AOA to AOB or the rate of nitrification in the water column and sediment of the cold deep ocean at more than $1000 \mathrm{~m}$.

In this study, we quantified the amo $A$ genes of crenarchaeotal AOA and betaproteobacterial AOB in water columns and cold seep sediments in the deep ocean (more than 1000 $\mathrm{m})$ of the northeastern Japan Sea with competitive PCR (cPCR). We developed two competitors for AOA and AOB with environmental clones obtained from sediment samples used in this study. In addition, phylogenies of amo $A$ genes were also investigated with a PCR-cloning analysis. In order to clarify the potential of ammonia-oxidation by AOA and/or AOB under low temperature conditions, nitrite and nitrate concentrations in culture media for $\mathrm{AOM}$ were investigated at $4^{\circ} \mathrm{C}, 10^{\circ} \mathrm{C}$, and $20^{\circ} \mathrm{C}$ with samples of water columns and sediment as an inoculum.

\section{Materials and Methods}

\section{Sample collection}

Water column samples were collected from two depths, $2000 \mathrm{~m}$ (designated NR) and $2956 \mathrm{~m}$ (designated NY), in the northeastern Japan Sea $\left(43^{\circ} 20^{\prime} \mathrm{N}, 1^{\circ} 9^{\circ} 39^{\prime} \mathrm{E}\right)$ using Niskin bottles deployed on the manned research submersible Shinkai 6500 (dive no. 6K960) on cruise YK06-07 in June 2006. Temperatures at both depths were $0.2^{\circ} \mathrm{C}$. NY was collected just above cold seep sediments where bacterial white mats had developed $\left(43^{\circ} 20.21^{\prime} \mathrm{N}, 139^{\circ} 39.85^{\prime} \mathrm{E}\right)$. Water samples were stored at $4^{\circ} \mathrm{C}$ and transferred to the laboratory within three days after sampling. A $1300 \mathrm{ml}$ volume of sea-water was filtered with Millex ${ }^{\circledR}$-GP (pore size, 0.2 $\mu \mathrm{m}$, Millipore, Billerica, MA, USA). One-third of the filter for molecular analysis was kept in a $2 \mathrm{ml}$ centrifuge tube for DNA extraction and then frozen at $-20^{\circ} \mathrm{C}$ until DNA extraction. One-third of the filter for the incubation experiment was kept in a sterile plastic tube $(50 \mathrm{ml})$ with filtered sea-water.

Sediment samples were collected from site M1 $\left(43^{\circ} 20^{\prime} \mathrm{N}\right.$, $139^{\circ} 39^{\prime} \mathrm{E}$ ), described previously by Arakawa et al. ${ }^{2)}$, at the southern foot of the Shiribeshi seamount by using MBARI cores deployed on the Shinkai 6500 (dive no. 6K960). A core sample was collected from an area where small white microbial mats were observed (2965 m; 43⒚99' $\mathrm{N}$, $139^{\circ} 39.91^{\prime} \mathrm{E}$ ). Ten grams of pelagic brown sediment (designated CR) was obtained from the core at $0-5 \mathrm{~cm}$ below the seafloor (bsf). Another core sample was collected from an area where white microbial mats were observed (2961 m; $\left.43^{\circ} 20.22^{\prime} \mathrm{N}, 139^{\circ} 39.86^{\prime} \mathrm{E}\right)$. Ten grams of black sediment (designated $\mathrm{CBK}$ ) was obtained from the core at $5-10 \mathrm{~cm}$ bsf. It is presumed that sea water just above cold seep sediments contains molecular oxygen compared to the black sediment. Sediment samples were stored at $4^{\circ} \mathrm{C}$ and transferred to the laboratory within three days. A part of each sediment sample was kept in a $1.5 \mathrm{ml}$ centrifuge tube and then frozen at $-20^{\circ} \mathrm{C}$ until DNA extraction.

\section{Amplification of the amoA gene}

Nucleic acids were extracted from $0.5 \mathrm{~g}$ of sediment $(n=3)$ and filter $(n=1)$ with an ISOIL for Beads Beating Kit (Nippon Gene, Toyama, Japan) following the manufacturer's instructions, after vortexing vigorously the plastic tube containing lysis solutions and beads in the kit for 45 sec. Nucleic acids extracted in $20 \mu \mathrm{l}$ of Tris-EDTA (TE) buffer were stored at $-20^{\circ} \mathrm{C}$ until PCR. Partial amo $A$ gene fragments were amplified with TaKaRa EX Taq DNA polymerase (Takara Bio, Otsu, Japan). Nucleotide primers for the PCR were crenAMO_F and crenAMO_R for the crenarchaeotal amo $A$ gene ${ }^{9)}$, and $a m o A-1 \mathrm{~F}$ and $a m o A-2 \mathrm{R}$ for the betaproteobacterial amo $A$ gene ${ }^{26)}$. The amplification was performed with a MyCycler thermal cycler (BIO-RAD, Hercules, CA). The protocol for PCR cycling is described in Table 1. PCR products were visualized on a $1.5 \%(\mathrm{w} / \mathrm{v})$ agarose gel stained with ethidium bromide. Two reaction mixtures were pooled, excised from gels, and extracted with a QIAGEN II Gel Extraction Kit (QIAGEN, Valencia, CA). Amplified gene fragments of amoA were cloned with a TOPO TA PCR cloning kit (Invitrogen, Carlsbad, CA). White colonies were transferred to new LB broth agar plates with kanamycin, grown overnight at $37^{\circ} \mathrm{C}$, and amplified with the vector-specific primers M13F and M13R. After 
Table 1. Protocol for PCR cycling

\begin{tabular}{|c|c|c|c|}
\hline Primer set & Target gene & PCR cycle & Reference \\
\hline crenAMO_F and crenAMO_R & crenarchaeotal $a m o A$ gene & $\begin{array}{l}94^{\circ} \mathrm{C} \text { for } 5 \mathrm{~min}, 25 \text { to } 35 \mathrm{cycles} \text { of } 94^{\circ} \mathrm{C} \text { for } 30 \mathrm{sec}, 55^{\circ} \mathrm{C} \\
\text { for } 30 \mathrm{sec} \text {, and } 72^{\circ} \mathrm{C} \text { for } 45 \mathrm{sec} \text {, and final extension at } \\
72^{\circ} \mathrm{C} \text { for } 3 \mathrm{~min} \text {. }\end{array}$ & 9 \\
\hline amoA-1F and $a m o A-2 \mathrm{R}$ & betaproteobacterial amo $A$ gene & $\begin{array}{l}94^{\circ} \mathrm{C} \text { for } 5 \mathrm{~min} \text { and then } 25 \text { to } 35 \text { cycles of } 94^{\circ} \mathrm{C} \text { for } 30 \\
\text { sec, } 57^{\circ} \mathrm{C} \text { for } 30 \mathrm{sec} \text {, and } 72^{\circ} \mathrm{C} \text { for } 45 \mathrm{sec} \text {, and final } \\
\text { extension at } 72^{\circ} \mathrm{C} \text { for } 3 \mathrm{~min} \text {. }\end{array}$ & 26 \\
\hline NOC1-45f and NOC2-1168r & $\begin{array}{l}\text { 16S rRNA gene of gammaproteobacterial } \\
\text { ammonia-oxidizing bacteria }\end{array}$ & $\begin{array}{l}94^{\circ} \mathrm{C} \text { for } 5 \mathrm{~min}, 25 \text { to } 35 \mathrm{cycles} \text { of } 94^{\circ} \mathrm{C} \text { for } 30 \mathrm{sec}, 61^{\circ} \mathrm{C} \\
\text { for } 30 \mathrm{sec} \text {, and } 72^{\circ} \mathrm{C} \text { for } 45 \mathrm{sec} \text {, and final extension at } \\
72^{\circ} \mathrm{C} \text { for } 3 \mathrm{~min} \text {. }\end{array}$ & 8 \\
\hline
\end{tabular}

PCR products were electrophoresed again in a $1.5 \%$ agarose gel to check the length of the bands, amplicons were purified with a QIAquick PCR purification kit (QIAGEN) prior to sequencing.

\section{Sequencing and phylogenetic analysis}

M13F/M13R PCR products were sequenced with a BigDye v.3.1 sequencing kit (PE Applied Biosystems, Foster City, CA) on a Model 3100 DNA sequencer (PE Applied Biosystems). M13F/M13R PCR products (archaeal and bacterial amo $A$ genes) were sequenced using vector primers M13F and M13R. Similarities of the amoA gene sequences were investigated in the databases of the National Center for Biotechnology Information and the DNA Data Bank of Japan using BLAST ${ }^{1)}$. Clones having $\geq 97 \%$ nucleotide sequence similarity in each sample (NR, NY, CR, and $\mathrm{CBK}$ ) were assigned to the same representative type. Deduced amino acid sequences for environmental amo $A$ genes were determined from 590 bp of AOA and 444 bp of AOB nucleotide sequences. The nucleotide and amino acid sequences were aligned by using the CLUSTAL W program within MEGA3 software ${ }^{15}$. Phylogenetic trees for amoA of AOA and AOB were based on 184 and 138 amino acid sequences, respectively. Phylogenetic trees were inferred by the neighbor-joining and maximum parsimony methods implemented in MEGA3. The p-distance (amino acids) model within the neighbor-joining method was used for amoA. Bootstrap values were determined from 1000 iterations.

\section{Construction of competitors}

The competitor DNA fragments were constructed according to a previously described method ${ }^{6,34)}$. The partial archaeal amoA gene fragment (540 bp) was amplified directly from Escherichia coli containing the vector designated pAOA with a partial amoA gene (CR-G3N006) using primers crenAMO_F and AamoA-TN1 (5'-ACTGGACTGTTATAGAACT-3'). The partial betaproteobacterial
amoA gene fragment (391 bp) was amplified directly from Escherichia coli containing the vector designated pAOB with a partial amoA gene (CR-G3N026) using BamoA-TN1 (5'-AACTGGATGATCACAGCA-3') and amoA-2R-TC (5'-CCCCTCTGCAAAGCCTTCTTC-3' $)^{23)}$. The amplified archaeal and betaproteobacterial amo $A$ gene fragments were reamplified with primers crenAMO_F and AamoA-TN2 (5'-CCCACTTTGACCAAGCGGCCATACTGGACTGTTATAGAACT-3' [primer crenAMO_R underlined]) for AOA, and BamoA-TN2 (5'-GGGGTTTCTACTGGTGGTAACTGGATGATCACAGCA-3' [primer amo $A-1 \mathrm{~F}$ underlined]) and amoA-2R-TC for AOB, respectively, and then cloned into the pCR2.1-TOPO vector with a TOPO TA PCR cloning kit. After incubation of E. coli at $37^{\circ} \mathrm{C}$, the plasmids were extracted with a Quantum Prep Plasmid Miniprep Kit (BIO-RAD), and then used for cPCR as the archaeal amoA competitor (designated cAOA) and bacterial amo $A$ competitor (designated $\mathrm{cAOB}$ ).

\section{$c P C R$}

To estimate the abundance of archaeal and bacterial amo $A$ genes in the water column and sediment samples, amplifications were performed as described above with 25$\mu \mathrm{l}$ volumes containing $0.5 \mu \mathrm{l}$ of extracted nucleic acids and $0.5 \mu \mathrm{l}$ of competitor $\mathrm{cAOA}$ or $\mathrm{cAOB}$ using primers crenAMO_F and crenAMO_R, and amoA-1F and amo $A$ 2R. PCR products were analyzed by electrophoresis in $2 \%$ (w/v) Nusieve 3:1 agarose (FMC, Rockland, ME) gels, and then photographed with UV transillumination and a Polaroid MP4 Instant Camera System. The images were analyzed with Photoshop CS2 (Adobe Systems Inc., San Joes, CA).

\section{Incubation experiments}

To investigate the potential oxidation of ammonia by AOA and/or AOB obtained from the deep ocean under lowtemperature conditions, incubation experiments were conducted with sea-water (NR and NY) and sediment (CR and 
CBK) samples using two types of media. Modified Artificial Sea Water (ASW-Cl) medium $\left.{ }^{21}\right)$ contained $\left(\mathrm{NH}_{4}\right)_{2} \mathrm{SO}_{4}$ $1.0 \mathrm{~g}, \mathrm{NaCl} 20 \mathrm{~g} \mathrm{MgCl}_{2} \cdot 6 \mathrm{H}_{2} \mathrm{O} 10 \mathrm{~g}, \mathrm{Na}_{2} \mathrm{SO}_{4} 3.91 \mathrm{~g} \mathrm{CaCl}_{2}$ $1.1 \mathrm{~g}, \mathrm{KCl} 0.66 \mathrm{~g}, \mathrm{NaHCO}_{3} 0.19 \mathrm{~g}, \mathrm{~K}_{2} \mathrm{HPO}_{4} 0.01 \mathrm{~g}, \mathrm{Fe}-$ EDTA (III) $0.01 \mathrm{~g}$, MOPS [3-( $N$-Morpholino) propanesulfonic acid] $10 \mathrm{~g}$, and $1 \mathrm{ml}$ of bromothymol blue solution (bromothymol blue $0.01 \mathrm{~g} \mathrm{l}^{-1}, \mathrm{Na}_{2} \mathrm{HPO}_{4} \cdot 2 \mathrm{H}_{2} \mathrm{O} 0.123 \mathrm{~g} \mathrm{l}^{-1}$, and $\mathrm{KH}_{2} \mathrm{PO}_{4} 0.005 \mathrm{~g} \mathrm{l}^{-1}$ in distilled water) in $1000 \mathrm{ml}$ of distilled water. The $\mathrm{pH}$ of the ASW and ASW-Cl media was adjusted to 8.0. Synthetic Crenarchaeota medium (SCM) ${ }^{14)}$ contained $\mathrm{NaCl} 26 \mathrm{~g}, \mathrm{MgCl}_{2} \cdot 6 \mathrm{H}_{2} \mathrm{O} 5 \mathrm{~g}, \mathrm{MgSO}_{4} \cdot 7 \mathrm{H}_{2} \mathrm{O} 5 \mathrm{~g}$, $\mathrm{CaCl}_{2} 1.5 \mathrm{~g}, \mathrm{KBr} 0.1 \mathrm{~g}, 1 \mathrm{ml}$ of nonchelated trace element mixture, $1 \mathrm{ml}$ of vitamin mixture (4-aminobenzoic acid 40 $\mathrm{mg} \mathrm{l}^{-1}$, D-biotin $10 \mathrm{mg} \mathrm{l}^{-1}$, nicotinic acid $100 \mathrm{mg} \mathrm{l}^{-1}$, calcium D-pantothenate $50 \mathrm{mg} \mathrm{l}^{-1}$, and pyridoxine dihydrochloride $150 \mathrm{mg} \mathrm{l}^{-1}$ dissolved in $10 \mathrm{mM}$ sodium phosphate buffer [pH 7.1]), $1 \mathrm{ml}$ of thiamin solution (thiamine chloride dihydrochloride $100 \mathrm{mg} \mathrm{l}^{-1}$ dissolved in $25 \mathrm{mM}$ sodium phosphate buffer $[\mathrm{pH} 3.4]$ ) and $1 \mathrm{ml}$ of vitamin $\mathrm{B}_{12}$ solution (cyanocobalamine $50 \mathrm{mg} \mathrm{l}^{-1}$ dissolved in distilled water), 1 $\mathrm{ml}$ of selenite-tungstate solution $\left(\mathrm{NaOH} \quad 0.4 \mathrm{~g} \mathrm{l} \mathrm{l}^{-1}\right.$, $\mathrm{Na}_{2} \mathrm{SeO}_{3} \cdot 5 \mathrm{H}_{2} \mathrm{O} 6 \mathrm{mg} \mathrm{l}^{-1}$, and $\left.\mathrm{Na}_{2} \mathrm{WO}_{4} \cdot 2 \mathrm{H}_{2} \mathrm{O} 8 \mathrm{mg} \mathrm{l}^{-1}\right), 10 \mathrm{ml}$ of $\mathrm{KH}_{2} \mathrm{PO}_{4}\left(4 \mathrm{~g} \mathrm{l}^{-1}\right), 1 \mathrm{ml}$ of bicarbonate solution $\left(\mathrm{NaHCO}_{3}\right.$ $\left.84 \mathrm{~g} \mathrm{l}^{-1}\right)$, and $1 \mathrm{ml}$ of $\mathrm{NH}_{4} \mathrm{Cl}(1 \mathrm{M})$ in $1000 \mathrm{ml}$ of distilled water. The $\mathrm{pH}$ of SCM was adjusted to 7.0. A plastic tube $(50 \mathrm{ml})$ containing filtered seawater with filtered cells was mixed well to use as an inoculum. Two spoonfuls of sediment were transferred into $50 \mathrm{ml}$ of filtered sea-water and then mixed well to make slurry samples. Three milliliters of the water and slurry sample was used to inoculate a hard cotton-wool-plugged 100-ml Erlenmeyer flask containing $30 \mathrm{ml}$ of ASW-Cl, and SCM, respectively, and incubated at $10^{\circ} \mathrm{C}$ and $20^{\circ} \mathrm{C}$ in the dark for 84 days. After the incubation, the flask was incubated at $4{ }^{\circ} \mathrm{C}$ in the dark. The concentration of nitrite in the medium was determined colorimetrically with Griess-Ilosvey reagent ${ }^{11}$ ) (quantitative limit, 5 $\mu \mathrm{M})$. Nitrate was measured with an ion chromatography system-1000 attached to an UltiMate 3000 Variable Wavelength Detector (DIONEX, Sunnyvale, CA) (quantitative limit, $5 \mu \mathrm{M})$.

\section{Nucleotide sequence accession numbers}

The amoA gene sequences were submitted to DDBJ/ EMBL/GenBank and have been assigned the following accession numbers: AB289348 to AB289401.

\section{Results and Discussion}

Quantitative analysis of the amoA gene in water columns

To study the distribution of microorganisms responsible for the oxidization of ammonia at low temperatures in water columns of the deep ocean, a quantitative analysis of the amo $A$ gene was performed with cPCR. The abundance of the amo $A$ gene of AOA in the water column NR at a depth of $2000 \mathrm{~m}$ was estimated at $6 \times 10^{1}$ copies $\mathrm{ml}^{-1}(n=1)$ (Fig. 1A). In this study, the quantitative limit was $1 \times 10^{1}$ copies $\mathrm{ml}^{-1}$. On the other hand, the amo $A$ gene of AOB was not detected by the 35 -cycle PCR in the water column NR. The detection limit of cPCR for the amoA gene of AOB at a cycle number of 35 was $1 \times 10^{2}$ copies $\mu \mathrm{l}^{-1}$ in the extracted nucleic acid solution. Moreover, the abundance of the amo $A$ gene of AOA was $1 \times 10^{3}$ copies $\mu 1^{-1}$ in the extracted nucleic
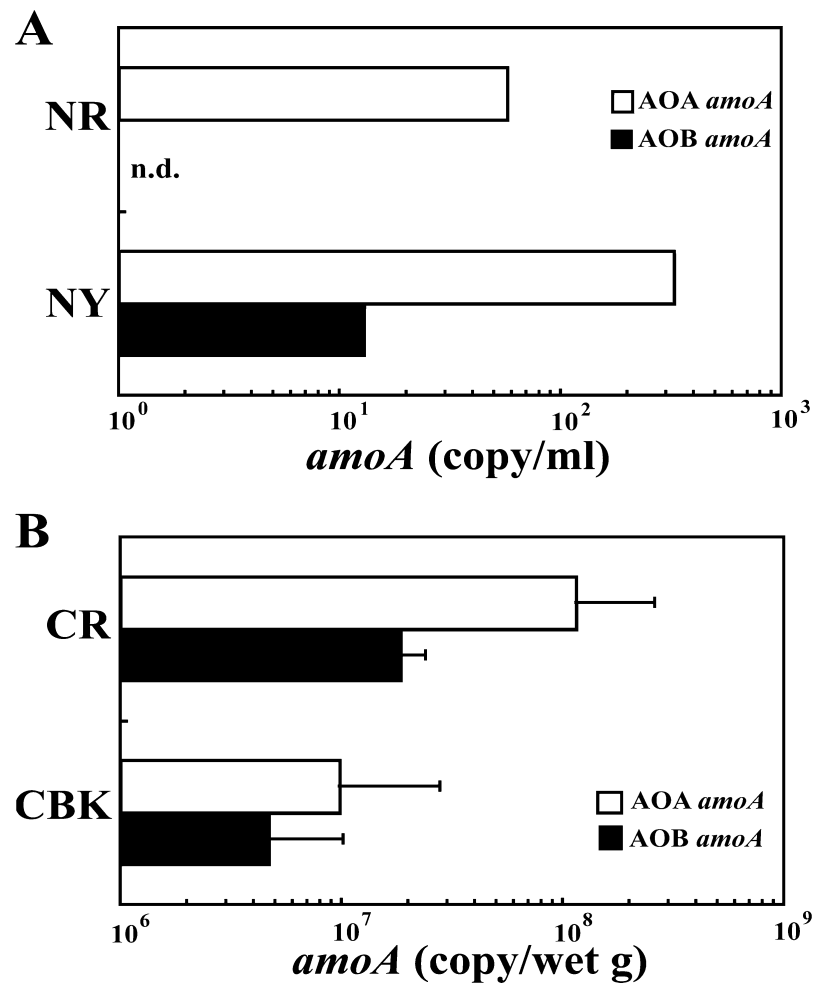

Fig. 1. Comparative abundance of amo $A$ genes between crenarchaeotal ammonia-oxidizing archaea (AOA) and betaproteobacterial ammonia-oxidizing bacteria (AOB). (A) Abundance of amoA genes in water columns. (B) Abundance of amo $A$ genes in cold seep sediment samples. NR, water column at a depth of $2000 \mathrm{~m}$; NY, water column at a depth of $2956 \mathrm{~m}$; CR, brown sediment ( 0 $5 \mathrm{~cm}$ bsf); CBK, black sediment (5-10 cm bsf). n.d. shows that the amo $A$ gene was not detected. In this study, quantitative limits were $1 \times 10^{1}$ copies $\mathrm{ml}^{-1}$. 
acid solution. Thus, the amoA gene of AOA can be estimated to be at least ten times more abundant than that of AOB in the water column NR $\left(0.2^{\circ} \mathrm{C}\right)$ at $2000 \mathrm{~m}$. Although these values are likely underestimated due to loss of nucleic acids during the extraction procedure, the ratio of gene abundance in AOA to AOB is considered accurate, if the PCR efficiency for AOA and AOB amplification is similar. Similarly, it has been reported that the abundance of the amoA gene of AOA was higher than that of $\mathrm{AOB}$ in the upper $1000 \mathrm{~m}$ of water columns of the North Atlantic Ocean $^{33)}$.

The abundance of amoA in the water column NY at a depth of $2956 \mathrm{~m}$ was estimated at $3 \times 10^{2}$ copies $\mathrm{ml}^{-1}$ for AOA $(n=1)$, and $1 \times 10^{1}$ copies $\mathrm{ml}^{-1}$ for $\mathrm{AOB}(n=1)$ (Fig. $1 \mathrm{~A})$. In this study, the quantitative limit was $1 \times 10^{1}$ copies $\mathrm{ml}^{-1}$. Therefore, it is concluded that the abundance of the amo $A$ gene of AOA was probably higher than that of AOB in water column NY at $2956 \mathrm{~m}$ just above cold seep sediments as well as in water column NR at a depth of $2000 \mathrm{~m}$. In addition, the abundance of the crenarchaeotal amo $A$ gene was greater at $2956 \mathrm{~m}$ than at $2000 \mathrm{~m}$. Abundance of marine Crenarchaeota group I reportedly increased in ambient cold seawater around deep-sea hydrothermal environments compared to normal seawaters ${ }^{29}$. It is known that hydrothermal fluids contain $\mathrm{CH}_{4}$ and $\mathrm{CO}_{2}$, and $\mathrm{NH}_{4}{ }^{+}$, depending on the sampling site ${ }^{17)}$. Methane was detected previously at this water column just above cold seep sediments ${ }^{2}$. It thus seemed that the nutrient flux from subseafloor induces an increase in the abundances of AOA and AOB in water columns.

\section{Quantitative analysis of the amoA gene in cold seep sediments}

The abundance of the amoA gene of AOA in sediment $\mathrm{CR}$ was estimated at $(1 \pm 2) \times 10^{8}$ copies $\mathrm{g}^{-1}$ [wet weight] $(n=3)$, while that of the $a m o A$ gene of AOB was estimated at $(2 \pm 2) \times 10^{7}$ copies $\mathrm{g}^{-1}(n=3)$ (Fig. 1B). This result demonstrated that the abundance of the amo $A$ gene of AOA was probably higher than that of AOB in brown sediment $\mathrm{CR}$ (0-5 cm bsf).

The abundance of the amoA gene of AOA in sediment CBK was estimated to be $(1 \pm 0.5) \times 10^{7}$ copies $\mathrm{g}^{-1}$ [wet weight] $(n=3)$, while that of the amoA gene of AOB was estimated at $(5 \pm 5) \times 10^{6}$ copies $\mathrm{g}^{-1}(n=3)$ (Fig. 1B). Therefore, it is concluded that the abundance of the amo $A$ gene of AOA was probably greater than that of AOB in black sediment CBK (5-10 cm bsf). Additionally, the amo $A$ genes of AOA and AOB were less abundant in black sediment CBK than in brown sediment CR (Fig. 1B). The smell of hydro- gen sulfide was detected in black sediment CBK. It is presumed that the amount of molecular oxygen is decreased in black sediment $\mathrm{CBK}$ compared to the layers above, because remarkable anaerobic oxidation of methane occurred with the detection of sulfate-reducing bacteria belonging to Deltaproteobacteria in black sediment ${ }^{2}$.

\section{Phylogenetic analysis of the amoA gene of $A O A$}

Sixteen representative clone types were obtained from 40 archaeal amo $A$ gene sequences of samples. Clones obtained from the water column NR fell mostly (90\%) into the phylogenetic cluster of the deep marine group containing the clone ETNP 4 from a water column of the Eastern Tropical North Pacific, the clone BS15.8.24 from a water column of the Black Sea ${ }^{7)}$, and HF500 and HF4000 from water columns of Monterey Bay and the Central Pacific, respectively) (Fig. 2). It has been reported that the clusters of the water columns $\mathrm{A}$ and $\mathrm{B}$ mostly consisted of amo $\mathrm{A}$ genes, suggesting that a significant portion of the archaeal community may be responsible for the first step of chemolithoautotrophic nitrification in water columns of the ocean $^{7}$. Similarly, it is likely that AOA corresponding to the amo $A$ genes within the cluster of the Deep Marine Group (water column B) are important microbial populations for nitrification in the water column NR at a depth of $2000 \mathrm{~m}$.

Clones obtained from sediment sample CR mostly (91\%) fell into the cluster of Sediment A including the amo $A$ gene of the chemolithoautotrophic ammonia-oxidizing archaeon 'Candidatus Nitrosopumilus maritimus' ${ }^{14)}$ (Fig. 2). The similarity of amoA gene sequences between CR clones within the cluster of Sediment A and those of 'Candidatus Nitrosopumilus maritimus' was $89 \%$ to $91 \%$. In addition, CR clones, that fell into the cluster of Sediment A-1, were less closely related to environmental clones retrieved from several environments (91\%-92\% nucleotide similarity). This clustering suggests that amoA genes within the Sediment A cluster represent a unique and psychrophilic AOA type in the deep-ocean cold seep sediments. Clones CR-G3N128 and CBK-G3N131 represented a separate lineage.

\section{Phylogenetic analysis of the amoA gene of $A O B$}

Nine representative clone types were obtained from 14 betaproteobacterial amo $A$ gene sequences of NY, CR, and CBK samples. All clones fell into the Nitrosospira cluster $^{25)}$ containing NEamoA-5 (96\% to $98 \%$ nucleotide similarity) and NFamoA-1 (96\% to $99 \%$ nucleotide similarity) detected in deep-ocean sediment in the Nankai Trough, Japan $^{30)}$. 


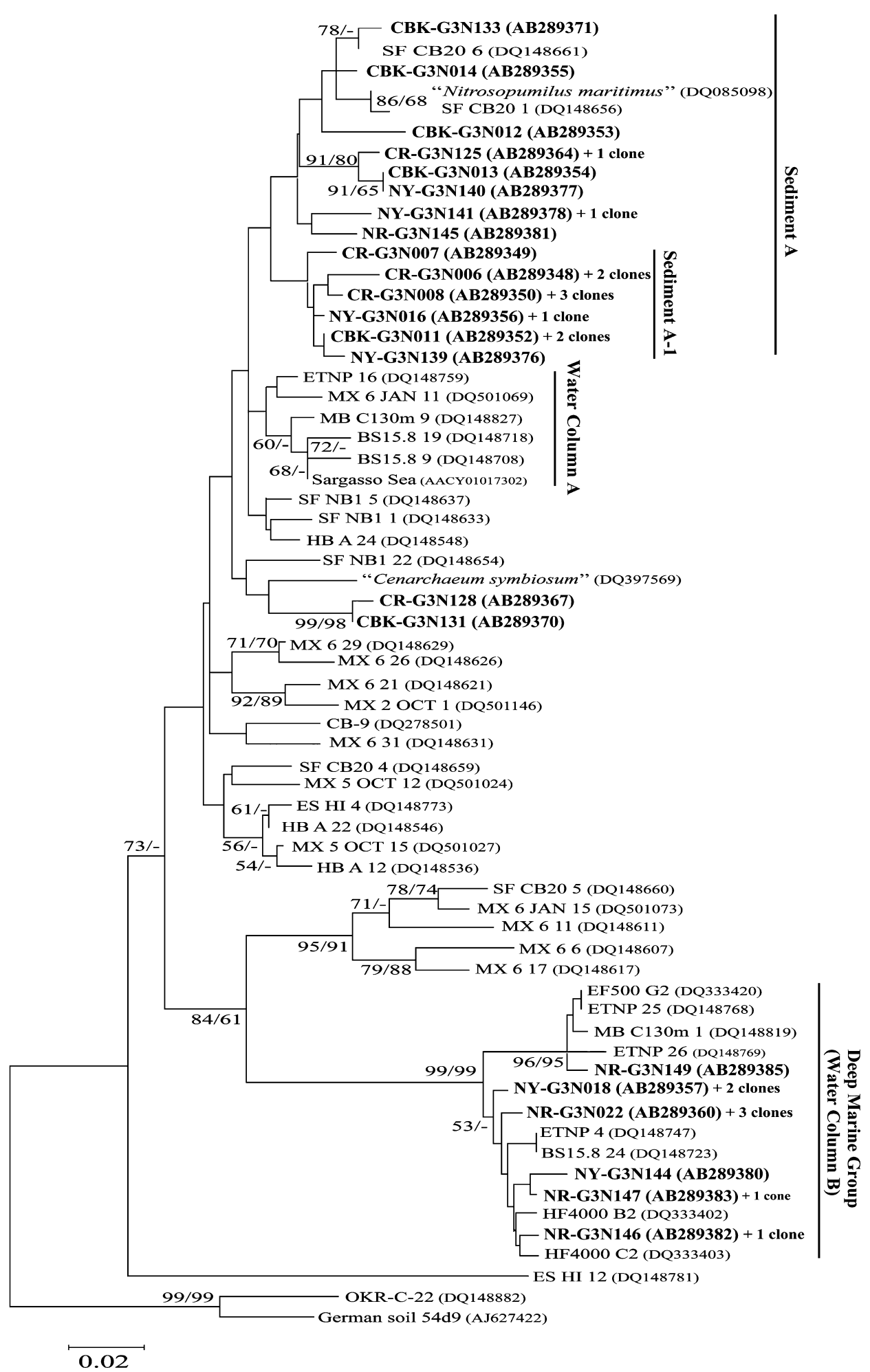

Fig. 2. Phylogenetic tree based on the deduced, partial amino acid sequences (184 length) of the archaeal amo $A$ gene as determined by neighborjoining analysis. Boldface type indicates $a m o A$ clones obtained in this study. The scale bar represents an estimated sequence divergence of $2 \%$. Numbers at nodes are bootstrap values $>50 \%$ that support the branching pattern appearing to the right of the value. Right sides of bootstrap values were determined by the maximum-parsimony method. German soil 54d9 (AJ627422) and OKR-C-22 (DQ148882) were used as the outgroup. Classification of the phylogenetic groups was described previously ${ }^{7,9)}$. 


\section{Gammaproteobacterial $A O B$}

To investigate the distribution of gammaproteobacterial AOB in water columns and sediment, we attempted to amplify the PCR product with a primer set for the $16 \mathrm{~S}$ rRNA gene of gammaproteobacterial $\mathrm{AOB}^{8}$ ). However, no PCR product was detected in any sample.

\section{Nitrite production at less than $10^{\circ} \mathrm{C}$}

To clarify the potential for ammonia-oxidation by AOA and/or AOB under low temperature conditions, nitrite concentrations in three types of media for $\mathrm{AOM}$ were determined after an 84 -day incubation at $10^{\circ} \mathrm{C}$ and $20^{\circ} \mathrm{C}$ in the dark. A remarkable difference in nitrite production was found at between $10^{\circ} \mathrm{C}$ and $20^{\circ} \mathrm{C}$ (Fig. 3). Remarkable nitrite production was observed in seven media (ASW-Cl$\mathrm{CR}$, -CBK, -NY, -NR, and SCM-CBK, -NY, -NR) for all cultures at $10^{\circ} \mathrm{C}$. The concentrations of nitrate in ASW-Cl$\mathrm{CR}$ and SCM-CR at $10^{\circ} \mathrm{C}$ were $5.6 \mu \mathrm{M}$ and $11.3 \mu \mathrm{M}$, respectively. Nitrate was not detected from other samples (detection limit, $5 \mu \mathrm{M}$ ). Furthermore, the nitrite concentrations in ASW-Cl-CR, -CBK, -NY, -NR, and SCM-NR kept increasing after the incubation temperature was changed to $4^{\circ} \mathrm{C}$ (Fig. 4). Therefore, these results demonstrated that nitrite production occurred at $4^{\circ} \mathrm{C}$, implying the potential for nitrite production in the deep ocean of the northeastern Japan Sea. It is, however, still unclear to what extent AOA and $\mathrm{AOB}$ might contribute to nitrite production. In addition, it is presumed that denitrification occurs during the incubation, because genes for denitrification have been detected in deep-sea sediment ${ }^{30)}$.

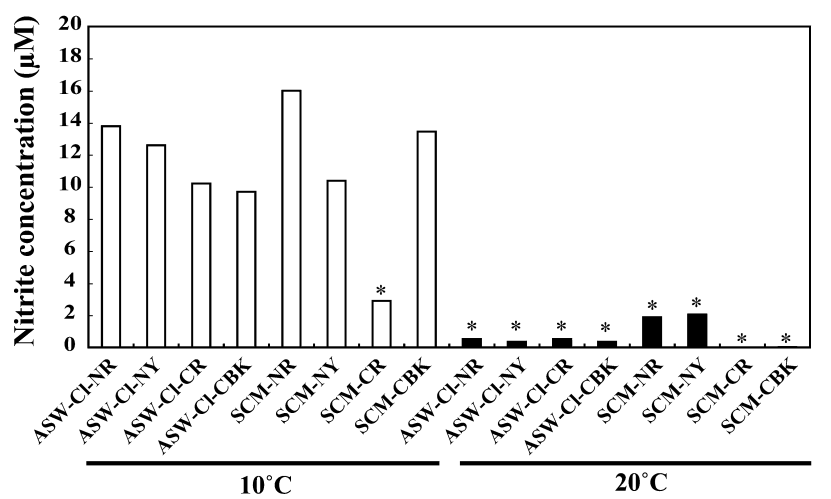

Fig. 3. Comparison of nitrite concentrations in culture media (ASW-Cl, and $\mathrm{SCM}$ ) at $10^{\circ} \mathrm{C}$ and at $20^{\circ} \mathrm{C}$ after 84-day incubations. NR and NY were water columns at depths of $2000 \mathrm{~m}$ and $2956 \mathrm{~m}$, respectively. CR, brown sediment CR (0-5 cm bsf); CBK, black sediment CBK (5-10 cm bsf). The asterisk shows that the concentration was less than the quantitative limit $(5 \mu \mathrm{M})$.

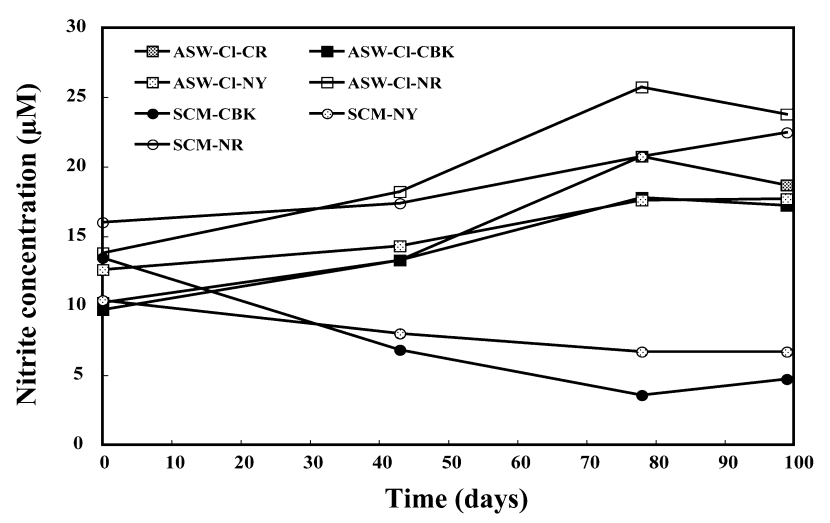

Fig. 4. Changes in nitrite concentrations in culture media at $4^{\circ} \mathrm{C}$ after 84 -day incubations at $10^{\circ} \mathrm{C}$. NR and NY were water columns at depths of $2000 \mathrm{~m}$ and $2956 \mathrm{~m}$, respectively. CR, brown sediment CR (0-5 cm bsf); CBK, black sediment CBK (5-10 cm bsf).

\section{Conclusion}

This study demonstrated that crenarchaeotal AOA were likely to be more abundant than beta- and gammaproteobacterial AOB in water columns and cold seep sediment of the deep ocean at a depth of more than $1000 \mathrm{~m}$. Furthermore, this study suggests that potential nitrite production takes place at $4^{\circ} \mathrm{C}$ in the water column at a depth of $2000 \mathrm{~m}$. Approximately $71 \%$ of the surface of the Earth is covered with oceans ${ }^{22}$. In addition, the deep ocean $\left(1-5^{\circ} \mathrm{C}\right.$; more than $1000 \mathrm{~m}$ ) is in area estimated to account for approximately $88 \%$ of the world's oceans ${ }^{18}$. Hence, it is important to clarify whether the psychrophilic AOM in the deep ocean play an important role in the global nitrogen and carbon cycles.

\section{Acknowledgements}

We are grateful to the captains and crews of the support vessel Yokosuka and the manned research submersible Shinkai 6500 as well as the operation teams of the Shinkai 6500 for their technical expertise. We wish to thank Mitsuaki Furuya (Nihon University) for his assistance in the incubation experiment, and to the staff of the General Research Institute (Nihon University) for their support in the sequencing. This work was supported by Nihon University Grant for Assistants and Young Researchers (2007).

\section{References}

1) Altschul, S.F., T.L. Madden, A.A. Schäfer, J. Zhang, Z. Zhang, W. Miller, and D.J. Lipman. 1997. Gapped BLAST and PSIBLAST: A new generation of protein database search programs. 
Nucleic Acids Res. 25:3389-3402.

2) Arakawa, S., T. Sato, R. Sato, J. Zhang, T. Gamo, U. Tsunogai, A. Hirota, Y. Yoshida, R. Usami, F. Inagaki, and C. Kato. 2006. Molecular phylogenetic and chemical analyses of the microbial mats in deep-sea cold seep sediments at the northeastern Japan Sea. Extremophiles 10:311-319.

3) Beman, J.M., and C.A. Francis. 2006. Diversity of ammonia-oxidizing archaea and bacteria in the sediments of a hypernutrified subtropical estuary: Bahía del Tóbari, Mexico. Appl. Environ. Microbiol. 72:7767-7777.

4) Bernhard, A.E., T. Donn, A.E. Giblin, and D.A. Stahl. 2005. Loss of diversity of ammonia-oxidizing bacteria correlates with increasing salinity in an estuary system. Environ. Microbiol. 7:1289-1297.

5) Briones, A.M., S. Okabe, Y. Umemiya, N.-B. Ramsing, W. Reichardt, and H. Okuyama. 2002. Influence of different cultivars on populations of ammonia-oxidizing bacteria in the root environment of rice. Appl. Environ. Microbiol. 68:3067-3075.

6) Celi, F.S., M.E. Zenilman, and A.R. Shuldiner. 1993. A rapid and versatile method to synthesize internal standards for competitive PCR. Nucleic Acids Res. 21:1047.

7) Francis, C.A., K.J. Roberts, J.M. Beman, A.E. Santoro, and B.B. Oakley. 2005. Ubiquity and diversity of ammonia-oxidizing archaea in water columns and sediments of the ocean. Proc. Natl. Acad. Sci. USA 102:14683-14688.

8) Freitag, T.E., and J.I. Prosser. 2003. Community structure of ammonia-oxidizing bacteria within anoxic marine sediments. Appl. Environ. Microbiol. 69:1359-1371.

9) Hallam, S.J., T.J. Mincer, C. Schleper, C.M. Preston, K. Roberts, P.M. Richardson, and E.F. DeLong. 2006. Pathways pf carbon assimilation and ammonia oxidation suggested by environmental genomic analyses of marine Crenarchaeota. PloS Biology 4:520 536.

10) Herndl, G.J., T. Reinthaler, E. Teira, H. van Aken, C. Veth, A. Pernthaler, and J. Pernthaler. 2005. Contribution of Archaea to total prokaryotic production in the deep Atlantic Ocean. Appl. Environ. Microbiol. 71:2303-2309.

11) Hewitt, E.J., and D.J.D. Nicholas (1964) Enzymes of inorganic nitrogen metabolism, p. 167-172. In H.F. Linskens, B.D. Sanwal, and M.V. Tracey (ed.), Modern methods of plant analysis. vol. 7. Springer, Gottingen and Heidelberg.

12) Ingalls, A.E., S.R. Shah, R.L. Hansman, L.I. Aluwihare, G.M. Santos, E.R.M. Druffel, and A. Pearson. 2006. Quantifying archaeal community autotrophy in the mesopelagic ocean using natural radiocarbon. Proc. Natl. Acad. Sci. USA 103:6442-6447.

13) Karner, M.B., E.F. DeLong, and D.M. Karl. 2001. Archaeal dominance in the mesopelagic zone of the Pacific Ocean. Nature 409:507-510.

14) Könneke, M., A.E. Bernhard, J.R. de la Torre, C.B. Walker, J.B. Waterbury, and D.A. Stahl. 2005. Isolation of an autotrophic ammonia-oxidizing marine archaeon. Nature 437:543-546.

15) Kumar, S., K. Tamura, and M. Nei. 2004. MEGA3: Integrated software for Molecular Evolutionary Genetics Analysis and sequence alignment. Brief. Bioinform. 5:150-163.

16) Leininger, S., T. Urich, M. Schloter, L. Schwark, J. Qi, G.W. Nicol, J.I. Prosser, S.C. Schuster, and C. Schleper. 2006. Archaea predominate among ammonia-oxidizing prokaryotes in soils. Nature 442:806-809.

17) Lilley, M.D., D.A. Butterfield, E.J. Olson, J.E. Lupton, S.A. Macko, and R.E. McDuff. 1993. Anomalous $\mathrm{CH}_{4}$ and $\mathrm{NH}_{4}{ }^{+}$concentrations at an unsedimented mid-ocean-ridge hydrothermal system. Nature 364:45-47.

18) Menard, H.W., and S.M. Smith. 1966. Hypsometry of ocean basin provinces. J. Geophys. Res. 71:4305-4325.

19) Mendum, T.A., R.E. Sockett, and P.R. Hirsch. 1999. Use of molecular and isotopic techniques to monitor the response of autotrophic ammonia-oxidizing populations of the $\beta$ subdivision of the class Proteobacteria in arable soils to nitrogen fertilizer. Appl. Environ. Microbiol. 65:4155-4162.

20) Mincer, T.J., M.J. Church, L.T. Taylor, C. Preston, D.M. Karl, and E.F. DeLong. 2007. Quantitative distribution of presumptive archaeal and bacterial nitrifiers in Monterey Bay and the North Pacific Subtropical Gyre. Environ. Microbiol. 9:1162-1175.

21) Mizoguchi, M., J. Omotani, Y. Mizuno, R. Takahashi, T. Kanehira, M. Shinohara, and T. Tokuyama. 1998. Newly isolated marine ammonia-oxidizing bacterium, Nitrosomonas sp. TNO632. J. Ferment. Bioeng. 86:406-409.

22) Morita, R.J. 2000. Low-temperature environments, p. 93-98. In J. Lederberg (ed.), Encyclopedia of Microbiology. second ed., vol. 3, Academic Press, San Diego.

23) Nicolaisen, M.H., and N.B. Ramsing. 2002. Denaturing gradient gel electrophoresis (DGGE) approaches to study the diversity of ammonia-oxidizing bacteria. J. Microbiol. Methods 50:189-203.

24) Oved, T., A. Shaviv, T. Goldrath, R.T. Mandelbaum, and D. Minz. 2001. Influence of effluent irrigation on community composition and function of ammonia-oxidizing bacteria in soil. Appl. Environ. Microbiol. 67:3426-3433.

25) Purkhold, U., M. Wagner, G. Timmermann, A. PommereningRöser, and H.-P. Koops. 2003. 16S rRNA and amoA-based phylogeny of 12 novel betaproteobacterial ammonia-oxidizing isolates: extension of the dataset and proposal of a new lineage within the nitrosomonads. Int. J. Syst. Evol. Microbiol. 53:14851494.

26) Rotthauwe, J.-H., K.-P. Witzel, and W. Liesack. 1997. The ammonia monooxygenase structural gene $a m o A$ as a functional marker: molecular fine-scale analysis of natural ammonia-oxidizing populations. Appl. Environ. Microbiol. 63:4704-4712.

27) Sinninghe Damsté, J.S., W.I.C. Rijpstra, E.C. Hopmans, F.G. Prahl, S.G. Wakeham, and S. Schouten. 2002. Distribution of membrane lipids of planktonic Crenarchaeota in the Arabian Sea. Appl. Environ. Microbiol. 68:2997-3002.

28) Schleper, C., G. Jurgens, and M. Jonuscheit. 2005. Genomic studies of uncultivated archaea. Nat. Rev. Microbiol. 3:479-488.

29) Takai, K., H. Oida, Y. Suzuki, H. Hirayama, S. Nakagawa, T. Nunoura, F. Inagaki, K.H. Nealson, and K. Horikoshi. 2004. Spatial distribution of marine crenarchaeota group I in the vicinity of deep-sea hydrothermal systems. Appl. Environ. Microbiol. 70:2404-2413.

30) Tamegai, H., R. Aoki, S. Arakawa, and C. Kato. 2007. Molecular analysis of the nitrogen cycle in deep-sea microorganisms from the Nankai Trough: genes for nitrification and denitrification from deep-sea environmental DNA. Extremophiles 11:269-275.

31) Treusch, A.H., S. Leininger, A. Kletzin, S.C. Schuster, H.-P. Klenk, and C. Schleper. 2005. Novel genes for nitrite reductase and Amo-related proteins indicate a role of uncultivated mesophilic crenarchaeota in nitrogen cycling. Environ. Microbiol. 7:1985-1995.

32) Ward, B.B., and G.D. O'Mullan. 2002. Worldwide distribution of Nitrosococcus oceani, a marine ammonia-oxidizing $\gamma$-proteobacterium, detected by PCR and sequencing of 16S rRNA and amoA genes. Appl. Environ. Microbiol. 68:4153-4157.

33) Wuchter, C., B. Abbas, M.J.L. Coolen, L. Herfort, J. van Bleijswijk, P. Timmers, M. Strous, E. Teira, G.J. Herndl, J.J. Middelburg, S. Schouten, and J.S. Sinninghe Damsté. 2006. Archaeal nitrification in the ocean. Proc. Natl. Acad. Sci. USA 103:12317-12322.

34) Yoshida, T., Y. Yuki, S. Lei, H. Chinen, M. Yoshida, R. Kondo, and S. Hiroishi. 2003. Quantitative detection of toxic strains of the cyanobacterial genus Microcystis by competitive PCR. Microbes Environ. 18:16-23. 